\title{
Experimental and kinetic study of steam gasification of low-rank coal in molten blast furnace slag
}

\author{
Wenjun Duan, Qingbo Yu*, Junxiang Liu, Tianwei Wu, Fan Yang, Qin Qin \\ School of Materials and Metallurgy, Northeastern University, No. 11, Lane 3, \\ Wenhua Road, Heping District, Shenyang 110819, Liaoning, People's Republic of \\ China. \\ *Corresponding author information: \\ Telephone/Fax: +86-024-83672216. \\ E-mail addresses: duanwenjn@ 163.com (W. J. Duan)

$$
\text { yuqb@smm.neu.edu.cn (Q. B. Yu) }
$$ \\ Mailing address: P.O, Box 345, Northeastern University, No. 11, Lane 3, Wenhua \\ Road, Heping District, Shenyang, Liaoning, P. R. China.
}




\section{Abstract}

In this study, the isothermal tests for steam gasification of Dezhou (DZ) low-rank coal with molten blast furnace slag (BFS) were performed in a lab-scale continuous gasification system, to investigate the status of gasification and syngas production. The results showed that molten BFS provided the heat needed for gasification reaction to ensure gasification is successful. The carbon conversion efficiency (CE), cold gasification efficiency (CGE) and percentage of combustible gas were higher than $85 \%, 100 \%$ and $87 \%$, respectively. Meanwhile, thermo-gravimetric kinetic experiments were conducted to obtain the role of BFS in low-rank coal gasification. The study found that carbon conversion at a certain time was significantly enhanced with BFS as heat carrier. The reactivity index of coal was also improved under this condition. The reactivity index of coal with steam to coal $(\mathrm{S} / \mathrm{C})$ ratio of 1:2 was approximately 1.98 times higher than that with $\mathrm{S} / \mathrm{C}$ ratio of 1:0 at $1673 \mathrm{~K}$. The most probable kinetic mechanism model of $\mathrm{DZ}$ low-rank coal turned from $\mathrm{D}_{2}$ model to $\mathrm{A}_{2}$ model. Not only was BFS the heat carrier, but also it was the active catalyst in low-rank coal gasification. Eventually, the catalytic mechanism of coal gasification using BFS as heat carrier was schematically proposed.

\section{Keywords:}

Molten blast furnace slag; Low-rank coal; Steam gasification; Kinetic analysis; Catalytic mechanism 


\section{Introduction}

Coal was the dominant energy resource in China, which was consumed about 3.5 billion tons in 2014. However, in spite of low-rank coal's quality and relatively low mark price, it had not been widely utilized than the utilization of the higher rank coal [1]. Facing the current situation, Chinese government had established an incentive policy to encourage the effective utilization of low-rank coal resource in 12th Five Year Plan [2]. Therefore, it was extremely necessary to develop and utilize the low-rank coal effectively.

Gasification had been considered as one of the most promising clean coal utilizing technologies that could convert the solid fuel to clean syngas [3]. Several researches had utilized the low-rank coal by the method of gasification [3-10]. Skodras [4] investigated the isothermal $\mathrm{CO}_{2}$ gasification of Greek low-rank coal in a tubular fixed-bed reactor. The conversion of coal was very sensitive to the temperature in pyrolysis and gasification process, and the gasification reaction rate was independent of particle size. The effect of composite $\left(\mathrm{K}_{2} \mathrm{CO}_{3}\right.$ and $\left.\mathrm{CaO}\right)$ on gasification of low-rank coal was studied in a fixed-bed reactor at atmospheric pressure by Fan et al [3]. Through their researches, the composite catalyst not only enhanced the reaction, but also improved the syngas composition. The same conclusion was also obtained by Kopyscinski et al [5-8]. Zhang et al [9] investigated the catalytic effects of $\mathrm{Na}$ and $\mathrm{Ca}$ from inexpensive materials on in suit steam gasification of low-rank coal. The $\mathrm{Na}$ and Ca catalysts showed the remarkable activity for gasification reaction, but the primary char gasification efficiency was only 70\%. Rizkiana et al [10] utilized the biomass ash 
as the catalyst to improve the gasification rate of low-rank coal. It was found that biomass ash with high content of alkali and alkaline earth metal and low content of silica could be applied as a catalyst of low-rank coal gasification.

From above all researches, we found that the current studies of utilizing low-rank coal in gasification process were mainly forced on enhancing the gasification rate. However, the low-rank coal gasification efficiency and carbon conversion were not significantly improved due to the specificity of low-rank coal in its compositions and structure. In 2004, Liu [11] proposed the concept of coal gasification reaction using molten BFS as heat carrier to produce syngas. Based on this theory, an attempt was made to explore the potential of producing syngas and recovering waste heat of slag by Duan [12-15]. His study found that the gasification efficiency and carbon conversion were significantly improved when the reaction occurred in molten BFS. Meanwhile, the clean syngas was obtained by this method. Sun et al [16-18] also used this method to facilitate the sludge gasification reaction. Li [19] investigated the coal gasification in molten BFS at atmospheric pressure at $1573 \mathrm{~K} \sim 1773 \mathrm{~K}$. The obtained results showed that the gasification method had wide adaptability on coal particles. The carbon conversion and reaction rate were sensitive to BFS, which acted as a good catalyst [20]. The method of coal gasification using molten BFS as heat carrier not only effectively improved the gasification efficiency and reaction rate, but also recovered the high-quality waste heat of slag. Therefore, it was meaningful to take a research on gasification of coal using molten BFS as heat carrier and catalyst.

The main object of this study was to investigate the operating condition of low-rank 
coal gasification in molten BFS using a lab-scale continuous gasification system. On the other hand, BFS was studied in gasification process by thermo-gravimetric kinetic experiment and established the kinetic model of low-rank coal gasification in molten BFS. Ultimately, the mechanism of steam gasification of low-rank coal in molten BFS was studied, so as to present a theoretical instruction for the practical production.

\section{Materials and methods}

\subsection{Feedstock characterization}

The feedstock considered was DZ low-rank coal that was sieved and dried. The mean particle size of coal was $75 \mu \mathrm{m}$, which was crushed by a hammer, crusher and then sieved by a series sieve shakers. The ultimate analysis of the coal sample was conducted using a CHNS/O Analyzer, Perkin Elmer PE 2400 series II. The proximate analysis of the coal sample was conducted using an automatic coal proximate analyzer.

The ultimate and proximate of the DZ low-rank coal sample were shown in Table 1.

Table 1 Proximate and ultimate analysis of DZ low-rank coal sample

\begin{tabular}{|c|c|c|c|c|}
\hline \multicolumn{5}{|c|}{ Proximate analysis (wt.\%) } \\
\hline Moisture & Volatile matter & Fixed carbon & Ash & \\
\hline 4.96 & 4.82 & 19.11 & 71.11 & \\
\hline \multicolumn{5}{|c|}{ Ultimate analysis (wt.\%) } \\
\hline Carbon & Hydrogen & Nitrogen & Sulfur & Oxygen \\
\hline 21.57 & 0.710 & 0.19 & 0.457 & 1.003 \\
\hline
\end{tabular}

The BFS was used as heat carrier and reaction zone in the experiment, which was 
supplied by a factory in China. The chemical composition of BFS was analyzed by X-ray fluoroscopy (XRF, SE-Explore, Bruker). The physical properties and chemical compositions of the BFS were shown in Table 2.

Table 2 Physical properties and chemical compositions of the BFS

\begin{tabular}{cc}
\hline Molten slag density $\left(\mathrm{kg} / \mathrm{m}^{3}\right)$ & $2.71 \times 10^{3}$ \\
Particle density $\left(\mathrm{kg} / \mathrm{m}^{3}\right)$ & $2.80 \times 10^{2}$ \\
Bulk density $\left(\mathrm{kg} / \mathrm{m}^{3}\right)$ & 950 \\
Melting point $(\mathrm{K})$ & 1553 \\
\hline Chemical composition $(\mathrm{wt} . \%)$ & \\
\hline $\mathrm{CaO}$ & 41.21 \\
$\mathrm{MgO}^{2}$ & 8.22 \\
$\mathrm{SiO}_{2}$ & 34.38 \\
$\mathrm{Al}_{2} \mathrm{O}_{3}$ & 11.05 \\
$\mathrm{Fe}_{2} \mathrm{O}_{3}$ & 2.78 \\
$\mathrm{TiO}_{2}$ & 0.35 \\
Other minor constituents & 2.01 \\
\hline
\end{tabular}

\subsection{Experiment characterization and procedure}

In this paper, the lab-scale continuous gasification experiment and thermo-gravity kinetic experiment were performed so as to understand the condition of gasification of the low-rank coal in molten BFS and the role of slag in this process.

2.2.1 Lab-scale continuous gasification experiment characterization and procedure

The low-rank coal gasification reaction in molten BFS was carried out on a 
self-design lab-scale continuous slagging gasification system. The slagging gasification system was composed of feeding system, primary reactor system, temperature measurement system, gas purification system, flow measurement system, gas composition analysis system and off-gas treatment system. The schematic diagrams of the experiment apparatus and primary reactor were shown in Fig. 1.

In a typical continuous experiment, the loaded reactor (BFS mass: $1.8 \mathrm{~kg}$, height: $300 \mathrm{~mm} \mathrm{[19])} \mathrm{was} \mathrm{placed} \mathrm{in} \mathrm{the} \mathrm{electric} \mathrm{furnace} \mathrm{and} \mathrm{heated} \mathrm{to} \mathrm{the} \mathrm{target} \mathrm{temperature.}$ The rated power, rated voltage and rated temperature of the electric furnace was 15 $\mathrm{KW}, 380 \mathrm{~V}, 1873 \mathrm{~K}$, respectively. The reactor was insulated with glass wool material to maintain the temperature of molten BFS. Furthermore, there was a temperature controller with a thermocouple (type K) placed next to the outer surface of the reactor to record and control the temperature. When the steam stream and the target temperature were stable after about half an hour, the powder feeder was opened and the pulverized coal was carried into the reactor by $\mathrm{N}_{2}$. At this time, the coal gasification reaction with steam was carried out in molten BFS. The composition of syngas was recorded by gas analyzer meter, and the powder feeder was closed after the gas composition stable for $30 \mathrm{~min}$. It represented the completion of the gasification reaction when the content of hydrogen reached to zero, and the next experiment could be carried out through repeating the above steps. 


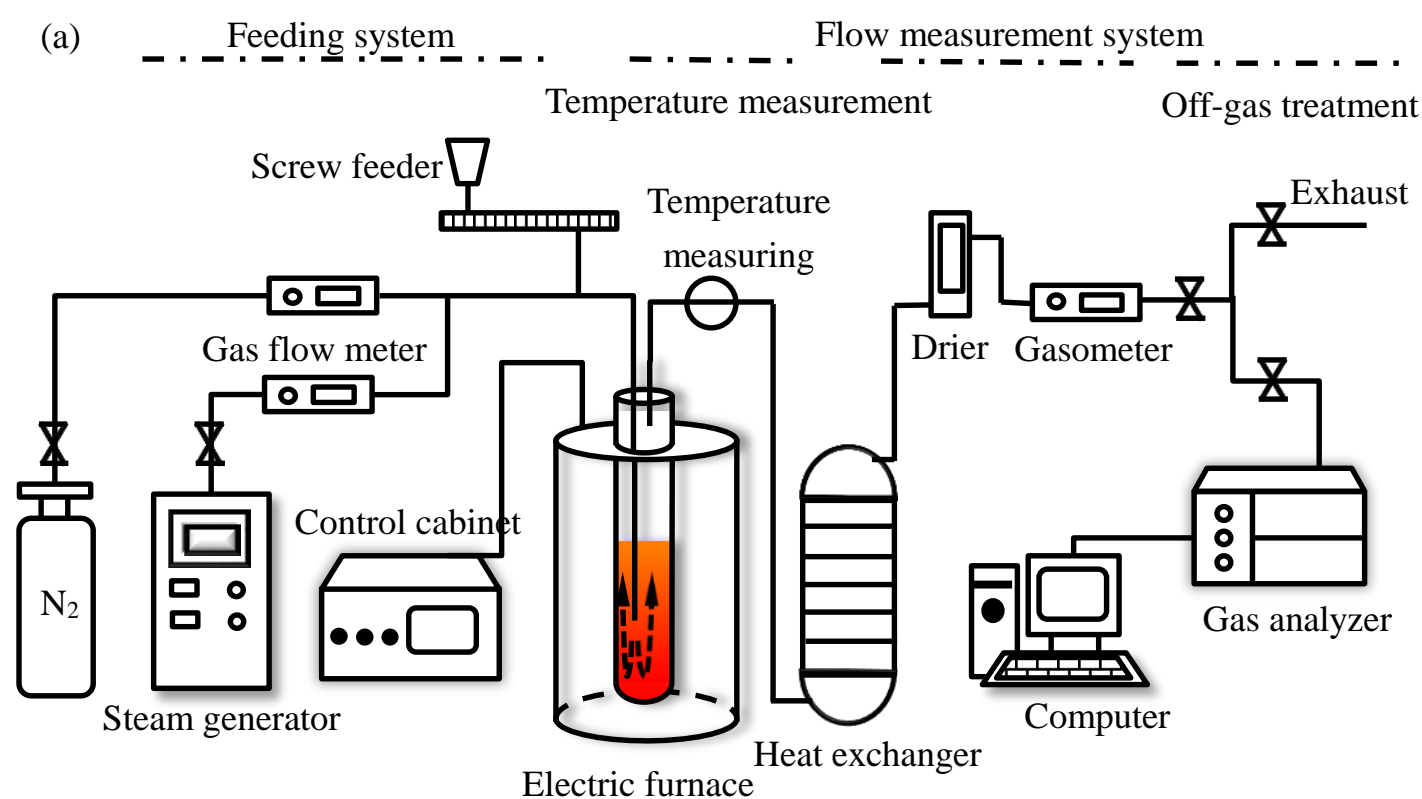

Electric furnace

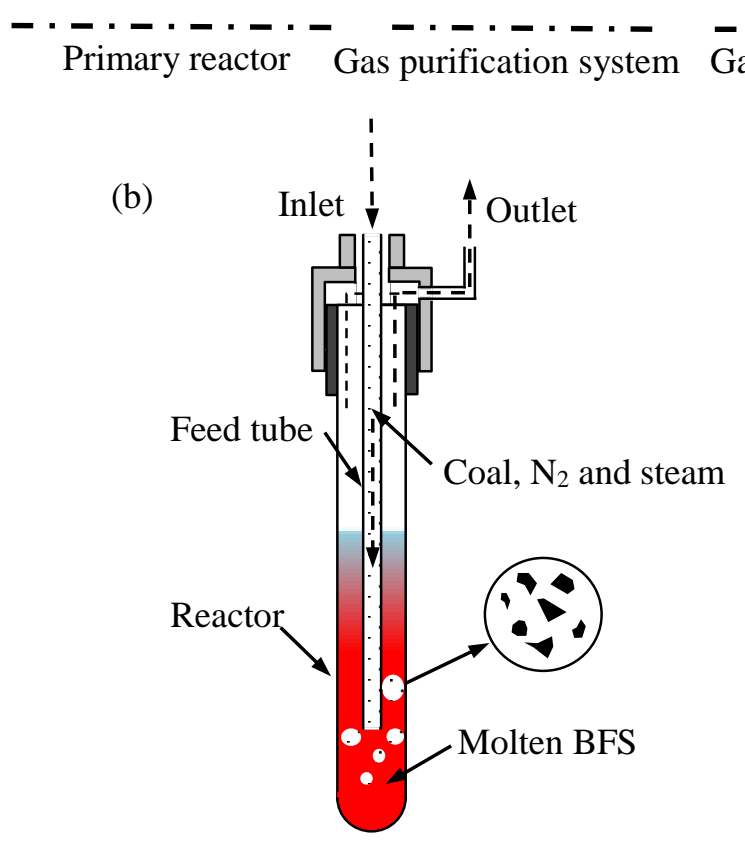

Fig. 1 The schematic diagram of the continuous experiment apparatus and primary reactor. (a)

$$
\text { Experiment apparatus, (b) Primary reactor }
$$

\subsubsection{Thermo-gravimetric kinetic experiment characterization and procedure}

A SETSYS Evolution TGA coupled with a steam generator and a Wet system was used to perform atmospheric steam gasification of DZ low-rank coal in molten BFS. The schematic diagram of the experiment apparatus was presented in Fig. 2. In the experiment, the sample was suspended by suspension wire, and the weight loss of 
the sample was recorded by electronic balance. The reaction gas flowed into reactor to form the circulation reaction area, and then flowed out when the reaction was completed. Ar flow was adopted as a protective gas and controlled with a control apparatus. The steam stream was controlled and heated to $423 \mathrm{~K}$ by steam generator. At last, the $75 \%$ steam and $25 \%$ Ar were adopted in the thermo-gravimetric kinetic experiment.

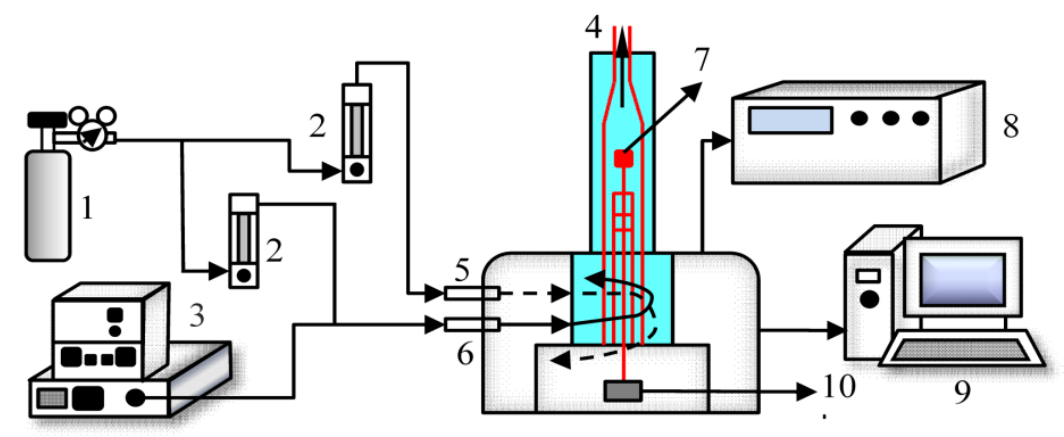

1. Ar cylinder; 2. Flowmeter; 3. Steam generator; 4. Gas outlet; 5. Protective gas 6. Gasification agent; 7. Crucible; 8. Temperature controller; 9. Computer; 10. Balance

Fig. 2 The schematic diagram of the thermo-gravimetric experiment apparatus

In the experiment, the sample was mixed with/without BFS and placed in an alundum crucible and Ar stream flowed through the balance at $50 \mathrm{~mL} \cdot \mathrm{min}^{-1}$ as the protective gas. As shown in Fig. 3, the low-rank coal preparation and gasification process were carried out consecutively in the thermo-gravimetric analyzer. The sample was pyrolyzed by heating to $1273 \mathrm{~K}$ at $20 \mathrm{~K} / \mathrm{min}$ under $\mathrm{Ar}$ atmosphere. The sample was maintained at $1273 \mathrm{~K}$ for $30 \mathrm{~min}$ to complete pyrolysis. After it, the sample was heated to desired temperature $(1573 \mathrm{~K}, 1623 \mathrm{~K}$ and $1673 \mathrm{~K})$ at $20 \mathrm{~K} / \mathrm{min}$ under Ar atmosphere. Then, the steam $\left(\mathrm{Vol} 75 \%, 50 \mathrm{~mL} \cdot \mathrm{min}^{-1}\right)$ mixed with Ar $(\mathrm{Vol}$ $25 \%, 16.5 \mathrm{~mL} \cdot \mathrm{min}^{-1}$ ) were flowed into the reactor to participate in the coal 
gasification reaction in molten BFS. The gasification reaction was run for $60 \mathrm{~min}$ to ensure completion of the reaction. During the sample preparation and gasification, the mass change of the sample could be measured by the thermo-gravimetric analyzer and recorded by a computer.

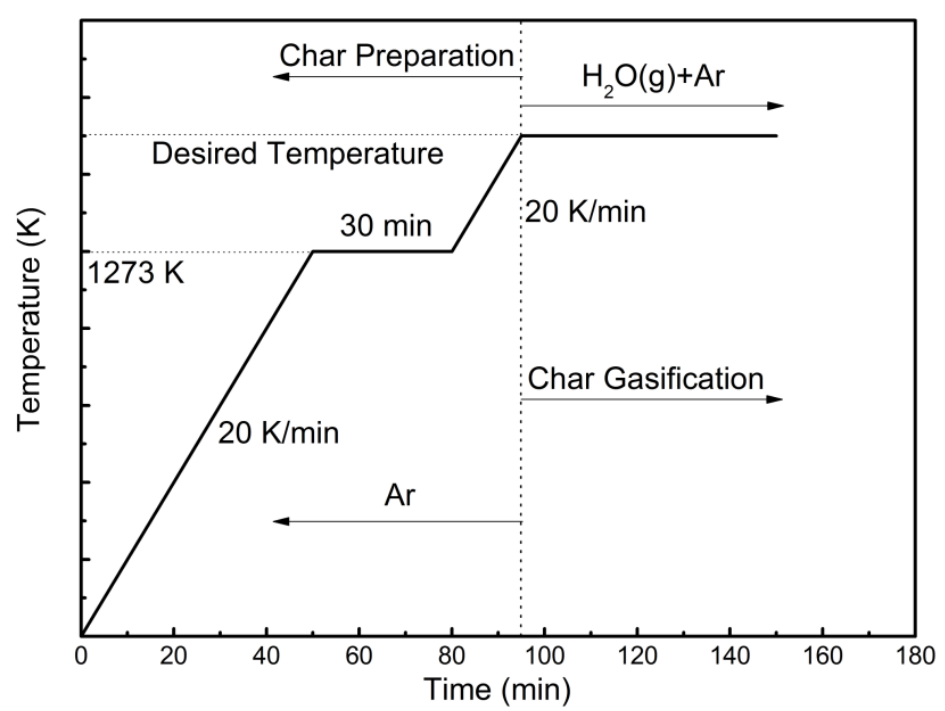

Fig. 3 The diagram of the thermo-gravimetric experiment procedure

\subsection{Experiment data analysis}

The carbon conversion efficiency (CE) was calculated by [22]:

$\mathrm{CE}(\%)=\frac{12\left(\mathrm{CO}+\mathrm{CO}_{2}\right) \mathrm{Y}_{\mathrm{G}, \mathrm{daf}}}{22.4 \mathrm{C}_{\mathrm{daf}}} \times 100 \%$

where, $\mathrm{Y}_{\mathrm{G}, \mathrm{daf}},\left(\mathrm{CO}+\mathrm{CO}_{2}\right)$ and $\mathrm{C}_{\mathrm{daf}}$ were the syngas yield, volumetric fraction of syngas compositions and mass of carbon in coal on dry and ash free basis, respectively.

The lower heating value (LHV) of dry syngas was defined as [23]:

$\mathrm{LHV}_{\text {syngas }}\left(\mathrm{MJ} / \mathrm{Nm}^{3}\right)=\left(108.0 \mathrm{H}_{2}+126.4 \mathrm{CO}\right) \times 10^{-3}$

The higher heating value (HHV) of the coal was calculated with a correlation presented in the literature $[24,25]$ :

$$
\begin{aligned}
\mathrm{HHV}_{\text {coal }}(\mathrm{MJ} / \mathrm{kg})= & 0.33(\text { Volatiles matter })-0.11 \text { (Moisture }) \\
& +0.35(\text { Fixed carbon })-0.03(\text { Ash })
\end{aligned}
$$


The lower heating value of the coal could be estimated by [26]:

$\mathrm{LHV}_{\text {coal }}(\mathrm{MJ} / \mathrm{kg})=\mathrm{HHV}_{\text {coal }}-9 m_{\mathrm{H}}\left(h_{f g}\right)$

where, $m_{\mathrm{H}}$ was the mass fraction of hydrogen in the coal, and $h_{f g}$ was the enthalpy of vaporization of water.

Based on the Eq. (2) and Eq. (4), the cold gasification efficiency (CGE) could be obtained:

$\mathrm{CGE}(\%)=\frac{\mathrm{LHV}_{\text {syngas }}\left(\mathrm{MJ} / \mathrm{Nm}^{3}\right) \times \mathrm{V}_{\text {syngas }}\left(\mathrm{Nm}^{3} / \mathrm{kg}\right)}{\mathrm{LHV}_{\text {coal }}(\mathrm{MJ} / \mathrm{kg})}$

The production syngas efficiency (PE) was calculated by [27]:

$\operatorname{PE}(\%)=\frac{\left(\mathrm{CO}+\mathrm{H}_{2}\right) \mathrm{Y}_{\mathrm{G}, \mathrm{daf}}}{22.4\left(\mathrm{n}_{\mathrm{C}}+\mathrm{n}_{\mathrm{H}_{2}}\right)}$

where, $\mathrm{n}_{\mathrm{C}}$ and $\mathrm{n}_{\mathrm{H}_{2}}$ were the mole of $\mathrm{C}$ and $\mathrm{H}_{2}$ in the coal, respectively.

\section{Results and discussion}

\subsection{Lab-scale continuous gasification experiment}

In this study, the lab-scale continuous gasification experiment proceeded so as to understand the gasification behavior of DZ low-rank coal in molten BFS. Fig. 4 showed the distribution of production syngas fraction of DZ low-rank coal gasification with $\mathrm{S} / \mathrm{C}$ ratio of 2.0 at $1573 \sim 1673 \mathrm{~K}$. The fraction of major combustible gases including $\mathrm{H}_{2}$ and $\mathrm{CO}$ showed an obvious status in the production syngas. The combustible gases, higher than $87 \%$ of the syngas, could be generated by gasification using molten BFS as heat carrier. In this production syngas, the fraction of $\mathrm{H}_{2}$ was higher than $58 \%$, which was beneficial to apply it into chemical products synthesis, 
fuel cell, and hydrogen-enriched syngas. This result was due to the effect of the BFS. With the presence of $\mathrm{CaO}$ in the $\mathrm{BFS}, \mathrm{CO}_{2}$ in the production syngas was absorbed and converted to $\mathrm{CaCO}_{3}$, thus shifted the water gas shift reaction and enhanced the $\mathrm{H}_{2}$ concentration $[28,29]$. In addition, metal oxides could prevent the formation of stable chemical structures in hydrocarbons, speed up the degradation of hydrocarbons, weaken the $\mathrm{C}-\mathrm{C}$ bond and thereby reduce the activation energy of the gasification reaction $[30,31]$.

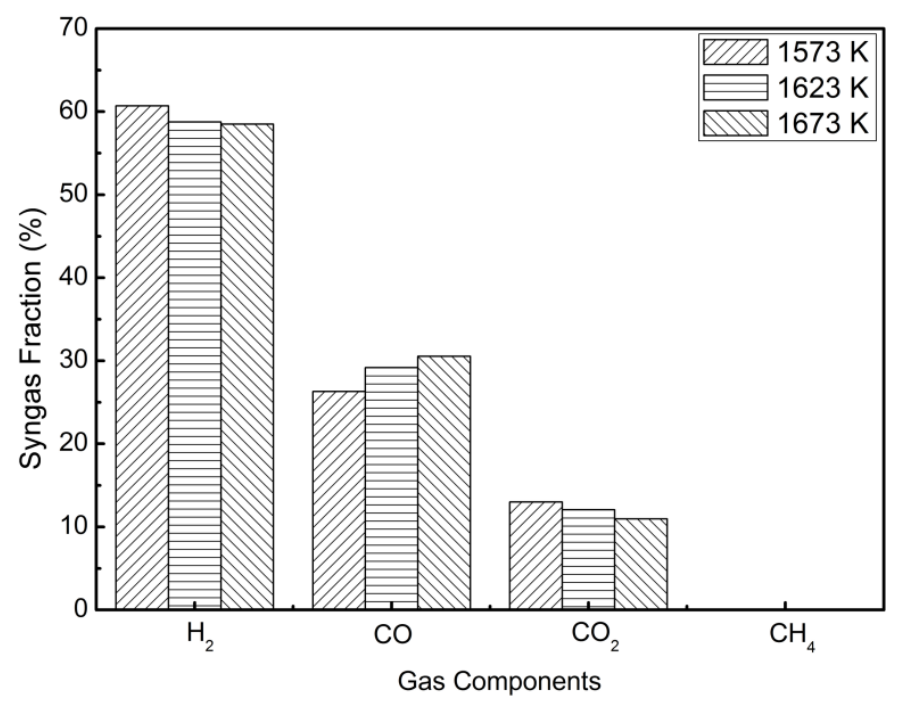

Fig. 4 The distribution of product syngas fraction of DZ low-rank coal in lab-scale continuous gasification experiment $(\mathrm{S} / \mathrm{C}$ ratio $=2.0)$

In the process of low-rank coal gasification in molten BFS, the heat needed for the gasification reaction was provided by hot molten BFS. The high-quality waste heat of slag was utilized effectively by this method, which both ensured the reaction working smoothly and the waste heat being utilized effectively. The same result was also obtained by Sun et al [16-21]. As could be seen from Fig. 5, the CE of the low-rank coal reached to $85 \%$. Especially, the CE reached up to $95 \%$ when the temperature was higher than $1623 \mathrm{~K}$. The CGE was higher than $100 \%$ because of the heat provided by 
slag, which was consistent with Duan and Wang's results by thermodynamic analysis $[12,32]$. Meanwhile, both PE and LHV of the syngas increased with an increasing temperature. The PE was also higher than $160 \%$ and the LHV of the syngas was 9.88 $\mathrm{MJ} / \mathrm{Nm}^{3}$ when the gasification temperature was $1573 \mathrm{~K}$. The maximum PE and LHV of syngas reached up to $174 \%$ and $10.18 \mathrm{MJ} / \mathrm{Nm}^{3}$ at $1673 \mathrm{~K}$, respectively.

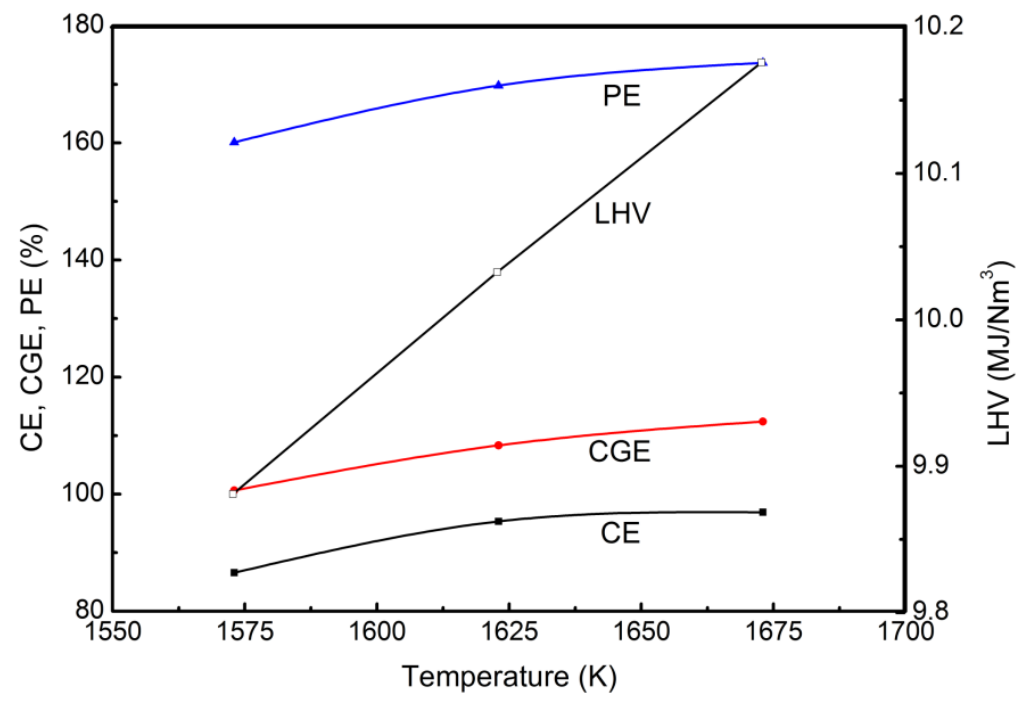

Fig. 5 The characteristic of CE, CGE, PE and LHV with different temperatures $(\mathrm{S} / \mathrm{C}$ ratio $=2.0)$

According to the above analysis, the problem of inefficient gasification of low-rank coal and the low heating value of production syngas could be effectively resolved by using molten BFS as heat carrier. By this method, the CE, CGE and PE were significantly improved, compared with the direct gasification [3, 4].

\subsection{Thermo-gravimetric kinetic experiment}

To further understand the BFS characteristics in low-rank coal gasification process, the reaction kinetics of the coal sample under steam atmosphere was tested by thermo-gravimetric analyzer. All the experiments were performed under isothermal condition at: $1573 \mathrm{~K}, 1623 \mathrm{~K}$ and $1673 \mathrm{~K}$ with the $\mathrm{C} / \mathrm{S}$ ratio of 1:0 and 1:2. 


\subsubsection{The effect of BFS on low-rank coal gasification}

During the experiment, the calculation method of carbon conversion was different between "pure" coal sample and coal blend with slag sample. The calculating method of carbon conversion could reference the earlier works $[19,20]$.

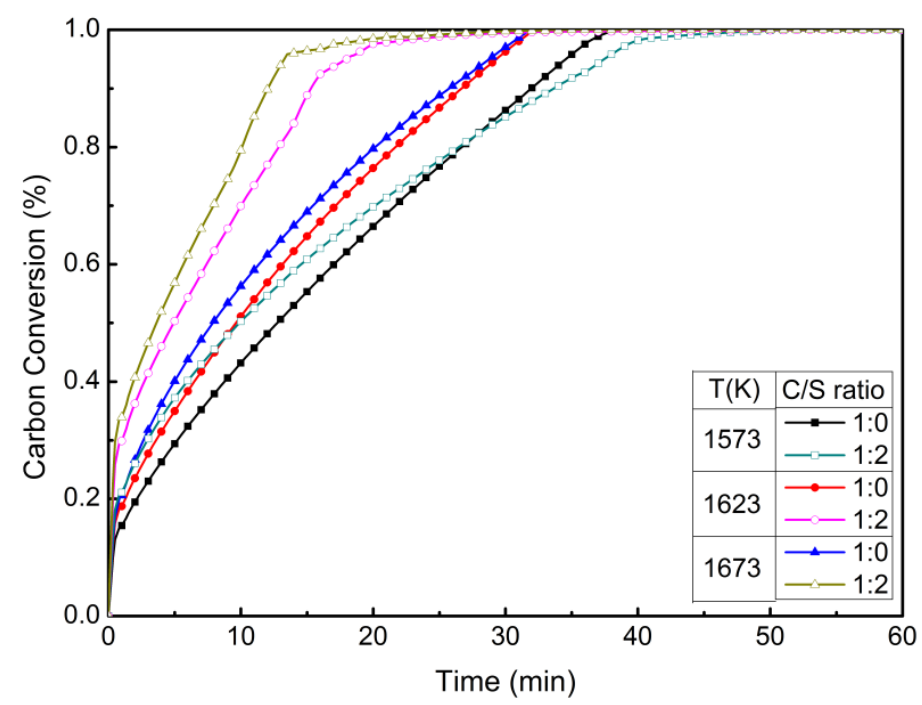

Fig. 6 Effect of C/S ratio on carbon conversion during the gasification of DZ low-rank coal at different temperatures

In this study, the thermo-gravimetric experiments of "pure" DZ low-rank coal $(\mathrm{C} / \mathrm{S}$ ratio $=1: 0)$ and coal mixed with slag $(\mathrm{C} / \mathrm{S}$ ratio $=1: 2)$ were conducted. The effect of $\mathrm{C} / \mathrm{S}$ ratio on carbon conversion at different temperatures was shown in Fig. 6. As could be seen from Fig. 6, the carbon conversion of the sample with $\mathrm{C} / \mathrm{S}$ ratio $=1: 2$ was higher than that with $\mathrm{C} / \mathrm{S}$ ratio $=1: 0$ at a certain reaction time and temperature. Compared with "pure" coal sample, the time for completing the carbon conversion was shorter than that with $\mathrm{C} / \mathrm{S}$ ratio $=1: 2$. It illustrated that the existence of the BFS had a significant impact on the coal gasification reaction [19-21, 33]. The molten BFS could act as an active catalyst in low-rank coal gasification process, which could be associated with the alkali and iron content. 
To further stretch the effect of $\mathrm{C} / \mathrm{S}$ ratio on steam gasification of DZ low-rank coal, the reactivity index was adopted. The reactivity index of gasification could be expressed as followed:

$$
R_{0.5}=\frac{0.5}{\tau_{0.5}}
$$

where, $R_{0.5}$ was the reactivity index of gasification, $\min ^{-1} ; \tau_{0.5}$ was the time necessary for carbon conversion reaching to $50 \%$, $\mathrm{min}$.

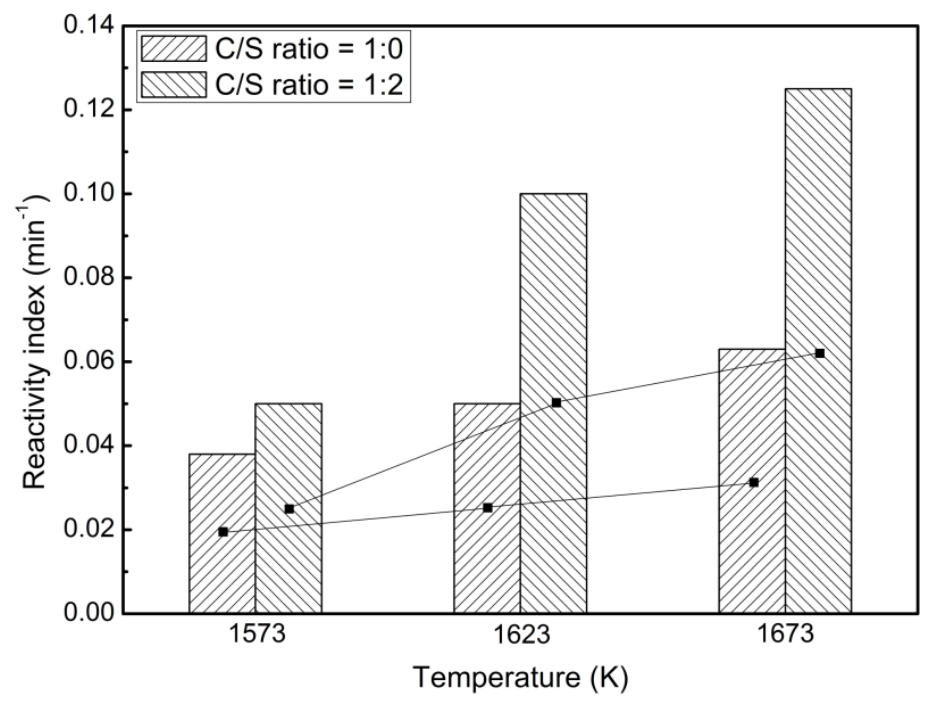

Fig. 7 Effect of $\mathrm{C} / \mathrm{S}$ ratio on reaction rate during the gasification of DZ low-rank coal at different

$$
\text { temperatures }
$$

Fig. 7 showed the effect of C/S ratio on reaction rate of the DZ low-rank coal gasification at different temperatures. At a certain temperature, the reactivity index of the coal with $\mathrm{S} / \mathrm{C}$ ratio of $1: 2$ was higher than that with $\mathrm{S} / \mathrm{C}$ ratio of 1:0. The reactivity index of the coal gasification was significantly improved when the BFS existed, especially at the $1623 \mathrm{~K}$ and $1673 \mathrm{~K}$. The reactivity index of coal with S/C ratio of 1:2 was approximately 1.98 times higher than that with $\mathrm{S} / \mathrm{C}$ ratio of 1:0 when the temperature was $1673 \mathrm{~K}$. That was to say, the BFS could act as an active catalyst and 
significantly enhance the reactivity index of DZ low-rank coal.

\subsubsection{Kinetic model of low-rank coal gasification in molten BFS}

In order to explain the low-rank coal gasification reaction with/without BFS, the kinetic mechanism should be further identified based on the data of carbon conversion vs. time. Based on the Vyazovkin's [34] and Li's [20, 21] results, various kinetic mechanism functions were used in this study (as summarized in Supplementary Table $\mathrm{S} 1$ ), so as to interpret the heterogeneous gas-solid coal gasification reaction and obtain the most probable function. The rate of coal gasification reaction could be deduced by the Eq. (8) [17]:

$F(x)=\int_{0}^{x} \frac{d x}{f(x)}=k(T) t$

where, $F(x)$ was the integral kinetic mechanism function; $x$ was the carbon conversion, \%; $t$ was the reaction time, min; $T$ was the absolute temperature, $\mathrm{K} ; f(x)$ was the differential kinetic mechanism function; $k(T)$ was the intrinsic surface reaction rate.

The various mechanism models fitting with the carbon conversion of DZ low-rank coal were showed in Fig. 8. Based on the square deviation $\left(R^{2}\right)$, the Diffusion model $\left(\mathrm{D}_{2}\right.$ model) showed a better result for the whole temperature when the gasification of low-rank coal was mixed without BFS. However, the most probable mechanism model of coal gasification reaction with BFS $(\mathrm{S} / \mathrm{C}=1: 2)$ was different with that of the "pure" coal. The Volumetric model ( $\mathrm{A}_{2}$ model) was selected as the most probable mechanism model. 

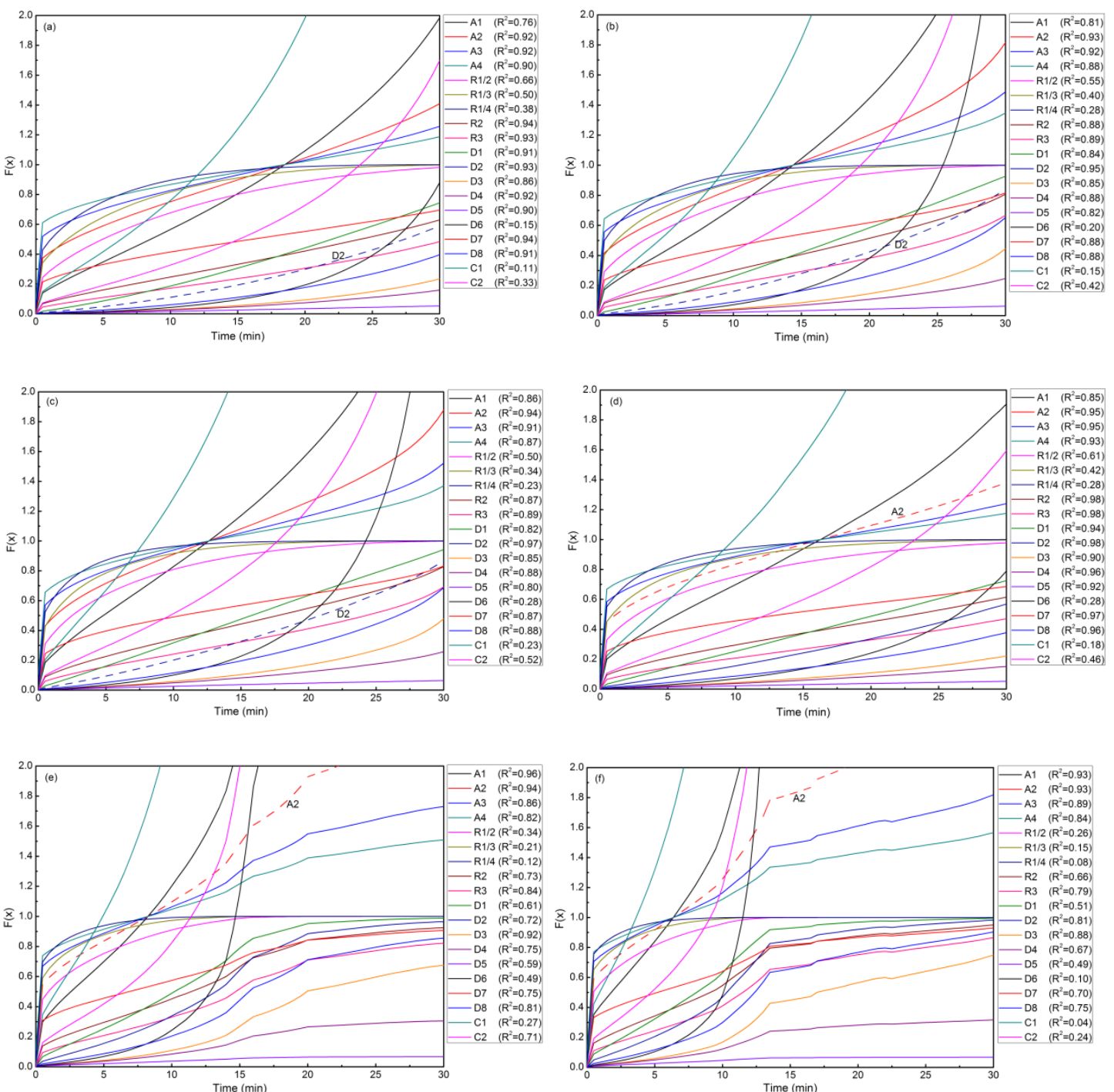

Fig. 8 Various mechanism models fitted with the carbon conversion of DZ low-rank coal

gasification. (a). $\mathrm{T}=1573 \mathrm{~K}, \mathrm{~S} / \mathrm{C}$ ratio $=1: 0 ;(\mathrm{b}) . \mathrm{T}=1623 \mathrm{~K}, \mathrm{~S} / \mathrm{C}$ ratio = 1:0; (c). $\mathrm{T}=1673 \mathrm{~K}$,

$\mathrm{S} / \mathrm{C}$ ratio $=1: 0 ;(\mathrm{d}) . \mathrm{T}=1573 \mathrm{~K}, \mathrm{~S} / \mathrm{C}$ ratio $=1: 2 ;(\mathrm{e}) . \mathrm{T}=1623 \mathrm{~K}, \mathrm{~S} / \mathrm{C}$ ratio $=1: 2 ;(\mathrm{f}) . \mathrm{T}=1673 \mathrm{~K}$,

$\mathrm{S} / \mathrm{C}$ ratio $=1: 2$

The mechanism variation by different models presented the prominent influence of slag on coal gasification. The gasification reaction was controlled by steam diffusion, when the coal gasification happened without slag. As for the coal gasification with molten BFS, the slag enhanced the heat transfer to accelerate the reaction rate and reacted with coal to form more porosity $[34,35]$. At this time, the rate controlling step 
was a nucleation process in the process of coal gasification reaction with molten BFS. The probable mechanism model changed from $\mathrm{D}_{2}$ model to $\mathrm{A}_{2}$ model when the coal gasification reaction using molten slag as heat carrier. It was in agreement with the Sun's result $[16,17]$, in which the model was determined by particles slag instead of molten slag.

Based on the Arrhenius equation, the intrinsic surface reaction rate could be expressed as followed:

$$
k(T)=k_{0} \exp \left(-\frac{E_{a}}{R T}\right)
$$

where, $E_{a}$ was the activation energy, $\mathrm{kJ} / \mathrm{mol}$; $k_{0}$ was the pre-exponential factor, $\mathrm{min}^{-1}$; $R$ was ideal gas law constant, $\mathrm{kJ} / \mathrm{mol} \cdot \mathrm{K} ; T$ was absolute temperature, $\mathrm{K}$.

By taking logarithm of both sides of Eq. (9), the Eq. (10) could be obtained to solve the $E_{\mathrm{a}}$ and $k_{0}$ from the slop and intercept of the plot $\ln k(T)$ vs. $1 / T$.

$$
\ln k(T)=\ln k_{0}-\frac{E_{a}}{R} \times \frac{1}{T}
$$

Table 3 The gasification rate equation and kinetic parameters of low-rank coal gasification with/without BFS

\begin{tabular}{ccc}
\hline $\mathrm{C} / \mathrm{S}$ & $1: 0$ & $1: 2$ \\
\hline Gasification rate equation & $r=\frac{d x}{d t}=k(T)[-\ln (1-x)]^{-1}$ & $r=\frac{d x}{d t}=2 k(T)(1-x)[-\ln (1-x)]^{\frac{1}{2}}$ \\
$E_{\mathrm{a}}(\mathrm{kJ} / \mathrm{mol})$ & $104.30 \pm 18.75$ & $36.74 \pm 10.28$ \\
$k_{0}\left(\mathrm{~min}^{-1}\right)$ & -0.88 & 4.69 \\
\hline
\end{tabular}

On the basis of calculation results, the global equation of low-rank coal gasification reaction with/without BFS was proposed, as shown in Table 3. As could be seen from the results, the $E_{\mathrm{a}}$ decreased significantly with the BFS addition and the gasification 
reaction of low-rank coal was dramatically enhanced. Therefore, the function of the molten BFS act as an active catalyst in gasification reaction was proven based on kinetic study once again.

\subsection{Proposed mechanism of steam gasification in molten BFS}

BFS was primarily composed of various oxides, such as $\mathrm{CaO}, \mathrm{SiO}_{2}, \mathrm{Al}_{2} \mathrm{O}_{3}, \mathrm{MgO}$, $\mathrm{Fe}_{2} \mathrm{O}_{3}$, and had very high thermal stability [36-38]. The main component of the BFS was demonstrated as a catalyst support in steam gasification of coal using molten BFS as heat carrier. Therefore, it was essential to establish a catalytic mechanism of steam gasification in molten slag in this study, so as to better understand and control the reaction process.

It was found that the catalysis of the molten BFS on steam gasification was especially pronounced between pyrolysis process and gasification process. In coal pyrolysis process, the fast pyrolysis reaction happened when the coal was injected into molten slag. It was because that the molten slag transferred its energy to the coal by radiation and heat transfer. The pyrolytic volatiles (condensable volatiles and condensable gas) and char were the main products of the pyrolysis, and then the cracking reaction of pyrolytic volatiles occurred to produce $\mathrm{H}_{2}, \mathrm{CO}, \mathrm{CO}_{2}, \mathrm{CH}_{4}, \mathrm{C}_{2}$.et al [39], as A1 reaction and A2 reaction shown in Fig. 9. By the research results of the Case et al [40], the intermediate products of the pyrolytic volatiles $\left(\mathrm{C}_{\mathrm{x}} \mathrm{H}_{\mathrm{y}} \mathrm{O}_{\mathrm{z}}\right)$ were difference when molten BFS existed. Polycyclic aromatic hydrocarbon (PAH) and phenols were formed by $\mathrm{C}_{x} \mathrm{H}_{y} \mathrm{O}_{z}$ cracking when the coal pyrolysis reaction happened in molten BFS. The catechols were produced by $\mathrm{C}_{\mathrm{x}} \mathrm{H}_{\mathrm{y}} \mathrm{O}_{\mathrm{z}}$ cracking when the reaction 
happened without slag. That was to say, the existed slag changed the product of the $\mathrm{C}_{\mathrm{x}} \mathrm{H}_{\mathrm{y}} \mathrm{O}_{z}$ cracking. $\mathrm{CaO}$ and metallic oxide in the slag catalyze deoxygenation in the form of dehydroxylation. This provided further insight into potential mechanistic pathways of the coal pyrolysis process [41]. Additionally, the existed molten BFS enhanced the heat transfer of the coal pyrolysis reaction, and this might be contributed to the product of the pyrolysis reaction.

In coal gasification process, catalysis effect of the molten BFS was mainly reflected in two aspects: (1) slagging catalyzed; (2) homogeneous reactions catalyzed by metals. For the slagging catalyzed process, the alkali carbonate in the BFS could catalyze the coal gasification reaction based on the following reactions [42, 43]. The carbon in the coal and the steam could be converted to $\mathrm{CO}$ and $\mathrm{H}_{2}$ rapidly and effectively. Both the carbon conversion and $\mathrm{H}_{2}$ production increased significantly by the catalyzed [44-46].

In the presence of the steam

$2 \mathrm{C}+\mathrm{M}_{2} \mathrm{CO}_{3} \leftrightharpoons 2 \mathrm{M}+3 \mathrm{CO}$

$2 \mathrm{M}+2 \mathrm{H}_{2} \mathrm{O} \leftrightharpoons 2 \mathrm{MOH}+\mathrm{H}_{2}$

$2 \mathrm{MOH}+\mathrm{CO} \leftrightharpoons \mathrm{M}_{2} \mathrm{CO}_{3}+\mathrm{H}_{2}$

Based on the Hess's law, the overall reaction was:

Primary water gas (PWG) reaction: $\mathrm{C}+\mathrm{H}_{2} \mathrm{O} \leftrightharpoons \mathrm{CO}+\mathrm{H}_{2}$

In the presence of the $\mathrm{CO}_{2}$

$2 \mathrm{C}+\mathrm{M}_{2} \mathrm{CO}_{3} \leftrightharpoons 2 \mathrm{M}+3 \mathrm{CO}$

$\mathrm{CO}_{2}+2 \mathrm{M} \leftrightharpoons \mathrm{M}_{2} \mathrm{O}+\mathrm{CO}$

$\mathrm{M}_{2} \mathrm{O}+\mathrm{CO}_{2} \leftrightharpoons \mathrm{M}_{2} \mathrm{CO}_{3}$ 
Based on the Hess's law, the overall reaction was:

Boudouard (BD) reaction: $\mathrm{C}+\mathrm{CO}_{2} \leftrightharpoons 2 \mathrm{CO}$

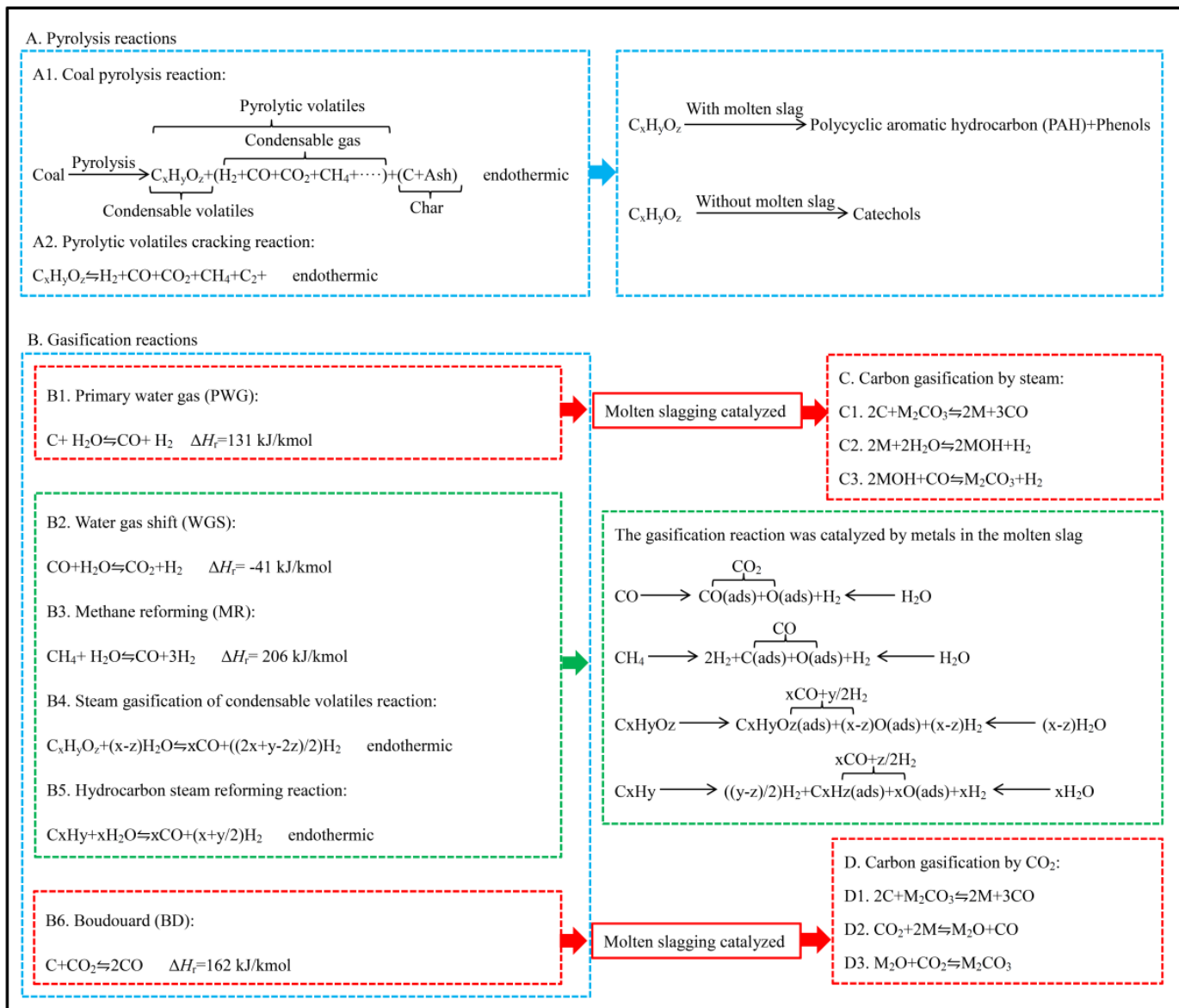

Fig. 9 The integrated catalytic mechanism of steam gasification in molten slag

There were many important homogeneous reactions happening in coal/steam gasification reaction, and improving the reaction rate of homogeneous reactions was very crucial to enhance the steam gasification in molten BFS. Based on the research results of $\mathrm{Li}$ et al [37, 47-51], the iron, manganese and magnesium in molten BFS could catalyze the coal gasification. The homogeneous reactions catalyzed by metals, the water gas shift reaction, Methane reforming reaction, steam gasification of condensable volatiles reaction and hydrocarbon steam reforming reaction were enhanced [47, 52, 53]. Meanwhile, the volatiles gases could be dissociated from 
molten slag $[47,54]$. Therefore, the molten BFS had a prominent impact on the steam gasification.

Based on the above analysis, it was essential to establish an integrated catalytic mechanism of steam gasification in molten slag, so as to present a theoretical instruction for understanding the experiment. Ratchahat et al [47] proposed the mechanism of $\mathrm{CO}_{2}$ gasification in MS-Ni medium, which was expressed in a sample, clear and systematic form. In this paper, the approach was adopted to establish the catalytic mechanism of steam gasification in molten slag, as shown in Fig. 9.

\section{Conclusions}

The experimental and kinetic studies of DZ low-rank coal gasification reaction in molten BFS were investigated. It was found that the low-rank coal could be utilized effectively by the gasification in the molten BFS. The CE, CGE and LHV of coal gasification were higher than $85 \%, 100 \%$ and $87 \%$, respectively. In gasification process, the reactivity index of coal was significantly improved due to the BFS addition. The global equation of low-rank coal gasification reaction with/without BFS was proposed by the kinetic experiment. The kinetic mechanism model of gasification changed from $\mathrm{D}_{2}$ model to $\mathrm{A}_{2}$ model with the BFS addition. The activation energy of gasification reduced from $104.30 \mathrm{~kJ} / \mathrm{mol}$ to $36.74 \mathrm{~kJ} / \mathrm{mol}$. On the basis of the results, the molten BFS not only provided the heat needed for the gasification reaction, but also acted as an active catalyst. Eventually, the integrated catalytic mechanism of steam gasification of coal using molten BFS as heat carrier was schematically 
proposed, so as to present a theoretical instruction for the practical production.

\section{Nomenclature}

$\mathrm{Y}_{\mathrm{G}, \mathrm{daf}}=$ the gas yield in the syngas, mol;

$\mathrm{C}_{\mathrm{daf}}=$ the mass of carbon in coal on dry and ash free basis, $\mathrm{g}$;

$m_{\mathrm{H}}=$ the mass fraction of hydrogen in the coal, \%;

$h_{f g}=$ the enthalpy of vaporization of water, $\mathrm{MJ} / \mathrm{kg}$;

$\mathrm{n}_{\mathrm{C}}=$ the mole of $\mathrm{C}$ in the coal, mol;

$\mathrm{n}_{\mathrm{H}_{2}}=$ the mole of $\mathrm{H}_{2}$ in the coal, mol;

$F(x)=$ the integral kinetic mechanism function;

$x=$ the carbon conversion, $\%$;

$t=$ the reaction time, $\min$;

$T=$ the absolute temperature, $\mathrm{K}$;

$f(x)=$ the differential kinetic mechanism function;

$k(T)=$ the intrinsic surface reaction rate;

$E_{a}=$ the activation energy, $\mathrm{kJ} / \mathrm{mol}$;

$k_{0}=$ the pre-exponential factor, $\min ^{-1}$;

$R=$ the ideal gas law constant, $\mathrm{kJ} / \mathrm{mol} \cdot \mathrm{K}$;

$R_{0.5}=$ the reactivity index of gasification, $\mathrm{min}^{-1}$;

$\tau_{0.5}=$ the time necessary for carbon conversion reaching to $50 \%, \mathrm{~min}$. 


\section{Abbreviations}

BFS $=$ Blast furnace slag

DZ coal $=$ Dezhou coal

$\mathrm{CE}=$ Carbon conversion efficiency

CGE $=$ Cold gasification efficiency

$\mathrm{PE}=$ Production syngas efficiency

LHV = Lower heating value

HHV = Higher heating value

$\mathrm{C} / \mathrm{S}$ ratio $=$ Coal to slag ratio

\section{Acknowledgements}

This research was supposed by The National Natural Science Foundation of China (51274066, 51304048), The National Science Foundation for Post-doctoral Scientists of China (2015M571322), The National Key Technologies R\&D Program of China (2013BAA03B03), The Fundamental Research Funds for the Central Universities (N130402019). We would very appreciate the reviewers' constructive comment on the manuscript.

\section{References}

1. Zhang DX, Liu P, Lu XL, Wang LL, Pan TY. Upgrading of low rank coal by hydrothermal treatment: Coal tar yield during pyrolysis. Fuel Processing Technology 2015; 141: 117-122. 
2. Zhuang QL, Biondi M, Yan SH, Bhagat K, Vansickle R, Chen C, Tan HJ, Zhu Y, You W, Xia W. TRIGTM: An advanced gasification technology to utilize low rank coals for power. Fuel 2015; 152: 103-109.

3. Fan SM, Yuan XZ, Zhao L, Xu LH, Kang TJ, Kim HT. Experimental and kinetic study of catalytic steam gasification of low rank coal with an environmentally friendly, inexpensive composite $\mathrm{K}_{2} \mathrm{CO}_{3}$-eggshell derived $\mathrm{CaO}$ catalyst. Fuel 2013; 165: 397-404.

4. Skodras G, Nenes G, Zafeirious N. Low rank coal- $\mathrm{CO}_{2}$ gasification: Experimental study, analysis of the kinetic parameters by Weibull distribution and compensation effect. Applied Thermal Engineering 2015; 74: 111-118.

5. Kopyscinski J, Lam J, Mims CA, Hill JM. $\mathrm{K}_{2} \mathrm{CO}_{3}$ catalyzed steam gasification of ash-free coal. Studying the effect of temperature on carbon conversion and gas production rate using a drop-down reactor. Fuel 2014; 128: 210-219.

6. Wang QH, Rong N, Fan HT, Meng YJ, Fang MX, Cheng LM, Cen KF. Enhanced hydrogen-rich gas production from steam gasification of coal in a pressurized fluidized bed with $\mathrm{CaO}$ as a $\mathrm{CO}_{2}$ sorbent. International Journal of Hydrogen Energy 2014; 39: 2781-2792.

7. Zhang B, Zhang L, Yang ZQ, Yan YF, Pu G, Guo M. Hydrogen-rich gas production from wet biomass steam gasification with $\mathrm{CaO} / \mathrm{MgO}$. International Journal of Hydrogen Energy 2015; 40: 8816-8823.

8. Sharma A, Matsumura A, Takanohashi T. Effect of $\mathrm{CO}_{2}$ addition on gas composition of synthesis gas from catalytic gasification of low rank coals. Fuel 
2015; 152: 13-18.

9. Zhang LX, Kudo S, Tsubouchi N, Hayashi J, Ohtsuka Y, Norinaga K. Catalytic effects of $\mathrm{Na} \mathrm{Ca}$ from inexpensive materials on in-suit steam gasification of char from rapid pyrolysis of low rank coal in a drop-tube reactor. Fuel Processing Technology 2013; 113: 1-7.

10. Rizkiana J, Guan GQ, Widaynatno WB, Hao XG, Li XM, Huang W, Abudula A. Promoting effect of various biomass ashes on the steam gasification of low-rank coal. Applied Energy 2014; 133: 282-288.

11. Liu HX. Investigation of coal gasification using blast furnace molten slag as heat carrier. Energy Conversion 2004; 6: 41-43.

12. Duan WJ, Yu QB, Xie HQ, Qin Q, Zuo ZL. Thermodynamic analysis of hydrogen-rich gas generation from coal/steam gasification using blast furnace slag as heat carrier. International Journal of Hydrogen Energy 2014; 39: 11611-11619.

13. Duan WJ, Yu QB, Zuo ZL, Qin Q, Li P, Liu JX. The technological calculation for synergistic system of BF slag waste heat recovery and carbon resources reduction. Energy Conversion and Management 2014; 87: 185-190.

14. Duan WJ, Yu QB, Wang K, Qin Q, Hou LM, Yao X, Wu TW. ASPEN Plus simulation of coal integrated gasification combined blast furnace slag waste heat recovery system. Energy Conversion and Management 2015; 100: 30-36.

15. Duan WJ, Li P, Lei W, Chen W, Yu QB, Wang K, Qin Q. Thermodynamic analysis of blast furnace slag waste heat-recovery system integrated with coal gasification. JOM 2015; 67(5): 1079-1084. 
16. Sun YQ, Zhang ZT, Liu LL, Wang XD. Two-stage high temperature sludge gasification using the waste heat from hot blast furnace slags. Bioresource Technology 2015; 198: 364-371.

17. Sun YQ, Zhang ZT, Liu LL, Wang XD. Integrated carbon dioxide/sludge gasification using waste heat from hot slags: Syngas production and sulfur dioxide fixation. Bioresource Technology 2015; 181: 174-182.

18. Sun YQ, Nakano J, Liu LL, Wang XD, Zhang ZT. Achieving waste to energy through sewage sludge gasification using hot slags: syngas production. Scientific Report 2015; 5: 11436-11448.

19. Li P, Yu QB, Qin Q, Liu JX. Adaptability of coal gasification in molten blast furnace slag on coal samples and granularities. Energy \& Fuels 2011; 25: $5678-5682$.

20. Li P, Yu QB, Qin Q, Lei W. Kinetics of $\mathrm{CO}_{2} /$ Coal gasification in molten blast furnace slag. Industrial \& Engineering Chemistry Research 2012; 51: $15872-15883$.

21. Li P, Lei W, Wu B, Yu QB. $\mathrm{CO}_{2}$ gasification rate analysis of coal in molten blast furnace slag-For heat recovery from molten slag by using a chemical reaction. International Journal of Hydrogen Energy 2015; 40: 1607-1615.

22. Tursun Y, Liu JG, Xu SP, Wei LG, Zuo WJ. Catalytic steam gasification of lignite olivine as solid heat carrier. Fuel 2013; 112: 641-645.

23. Wang RP, Huang QX, Lu P, Li WJ, Wang SK, Chi Y, Yan JH. Experimental study on air/steam gasification of leather scraps using U-type catalytic gasification for 
producing hydrogen-enriched syngas. International Journal of Hydrogen Energy 2015; 40: 8322-8329.

24. Jin H, Lu YJ, Liao B, Guo LJ, Zhang XM. Hydrogen production by coal gasification in supercritical water with a fluidized bed reactor. International Journal of Hydrogen Energy 2010; 35: 7151-7160.

25. Shabbar S, Janajreh I. Thermodynamic equilibrium analysis of coal gasification using Gibbs energy minimization method. Energy Conversion and Management $2013 ; 65: 755-763$.

26. Majumder AK, Jain R, Banerjee P, Barnwal JP. Development analysis of a new proximate analysis based correlation to predict calorific value of coal. Fuel 2008; 87(13-14): 3077-3081.

27. Xie KC, Yu JH, Wang FC. The technology of coal gasification. Chemical Industry Publishing House, Beijing, 2010.

28. Wang ZH, Zhou JH, Wang QH, Fan JR, Cen KF. Thermodynamic equilibrium analysis of hydrogen production by coal based on $\mathrm{Coal} / \mathrm{CaO} / \mathrm{H}_{2} \mathrm{O}$ gasification system. International Journal of Hydrogen Energy 2006; 31: 345-952.

29. Gomez A, Mahinpey N. A new method to calculate kinetic parameters independent of the kinetic model: Insights on $\mathrm{CO}_{2}$ and steam gasification. Chemical Engineering Research and Design 2015; 95: 346-357.

30. Vyazovkin S, Burnham AK, Criado JM, Perez-Maqueda LA, Popescu C, Sbirrazzuoli N. ICTAC kinetic committee recommendations for performing kinetic computations on thermal analysis data. Thermochimica Acta 2011; 520: 1-19. 
31. Xie QL, Kong SF, Liu YS, Zeng H. Syngas production by two-stage method of biomass catalytic pyrolysis and gasification. Bioresource Technology 2012; 110 : 603-609.

32. Jarungthammachote S, Dutta A. Equilibrium modeling of gasification: Gibbs free energy minimization approach and its application to spouted bed and spout-fluid bed gasifiers. Energy Conversion and Management 2008; 49: 1345-1356.

33. Li P, Yu QB, Qin Q, Du WY. The effects of slag compositions on the coal gasification reaction in molten blast furnace slag. Energy Sources, Part A 2014; 36: 73-79.

34. Wang SR, Zhang F, Cai QJ, Zhu LJ, Luo ZY. Steam reforming of acetic acid over coal ash supported Fe and Ni catalysts. International Journal of Hydrogen Energy 2015; 40: 11406-11413.

35. Wei LY, Yang HP, Li B, Wei XT, Chen L, Shao JG, Chen HP. Absorption-enhanced steam gasification of biomass for hydrogen production: Effect of calcium oxide addition on steam gasification of pyrolytic volatiles. International Journal of Hydrogen Energy 2014; 39: 15416-15423.

36. Case PA, Truong C, Wheeler MC, DeSisto WJ. Calcium-catalyzed pyrolysis of lignocellulosic biomass components. Bioresource Technology 2015; 192: 247-252.

37. Case PA, Wheeler MC, DeSisto WJ. Effect of residence time and hot gas filtration on the physical and chemical properties of pyrolysis oil. Energy \& Fuels 2014; 28 (6); 3964-3969.

38. Iwaki $\mathrm{H}$, Ye S, Katagiri H, Kitagawa K. Wastepaper gasification with $\mathrm{CO}_{2}$ or 
steam using catalysts of molten carbonates. Applied Catalysis A: General 2004; 270: $237-243$.

39. Rizkiana J, Guan GQ, Widayatno WB, Hao XG, Wang ZD, Zhang ZL, Abudula A. Oil production from mild pyrolysis of low-rank coal in molten salts media. Applied Energy 2015; 154: 944-950.

40. Eatwall-Hall REA, Sharifi VN, Swithenbank J. Hydrogen production from molten metal gasification. International Journal of Hydrogen Energy 2010; 35: 13168-13178.

41. Duman G, Watanabe T, Uddin MA, Yanik J. Steam gasification of safflower seed cake and catalytic tar decomposition over ceria modified iron oxide catalysts. Fuel Processing Technology 2014; 126: 276-283.

42. Ratchahat S, Kodama S, Tanthapanichakoon W, Sekiguchi H. Combined molten salt-Ni/ $\mathrm{Al}_{2} \mathrm{O}_{3}$ as synergistic medium for high-quality syngas production. Chemical Engineering Journal 2015; 278: 224-233.

43. Ratchahat S, Kodama S, Tanthapanichakoon W, Sekiguchi $\mathrm{H} . \mathrm{CO}_{2}$ gasification of biomass wastes enhanced by $\mathrm{Ni} / \mathrm{Al}_{2} \mathrm{O}_{3}$ catalyst in molten eutectic carbonate salt. International Journal of Hydrogen Energy 2015; 40(35): 11809-11822.

44. Domazeties G, James BD, Liesegang J, Raoarun M, Kuiper M, Potter ID, Oeheme D. Experimental studies and molecular modeling of catalytic steam gasification of brown coal containing iron species. Fuel 2012; 93: 404-414.

45. Alarcón N, García X, Centeno MA, Ruiz P, Gordon A. New effects during steam gasification of naphthalene: the synergy between $\mathrm{CaO}$ and $\mathrm{MgO}$ during the 
catalytic reaction. Applied Catalysis A: General 2004; 267(1-2): 251-265.

46. Zhuang HF, Han HJ, Hou BL, Jia SY, Zhao Q. Heterogeneous catalytic ozonation of biologically pretreated Lurgi coal gasification wastewater using sewage sludge based activated carbon supported manganese and ferric oxides as catalysts. Bioresource Technology 2014; 166: 178-186.

47. Zhang B, Zhang L, Yang ZQ, Yan YF, Ge P, Guo M. Hydrogen-rich gas production from wet biomass steam gasification with $\mathrm{CaO} / \mathrm{MgO}$. International Journal of Hydrogen Energy 2015; 40: 8816-8823.

48. Tao J, Zhao L, Dong C, Lu Q, Du X, Dahlquist E. Catalytic steam reforming of toluene as a model compound of biomass gasification tar using $\mathrm{Ni}-\mathrm{CeO}_{2} / \mathrm{SBA}-15$ catalysts. Energies 2013; 6: 3284-3296.

49. Kodama T, Isobe Y, Kondoh Y, Yamaguchi S, Shimizu KI. Ni/ceramic/molten-salt composite catalyst with high temperature thermal storage for use in solar reforming processes. Energy 2004; 29: 895-903.

50. Castagno F, Loschetter A, Seidelt S, Lelait L. Biosyngas cleaning by circulating in molten salt Bath: role of Thermal and catalytic effects. In: European biomass conference and exhibition (EU BC\&E); 2010. p. 715-722. 


\section{TABLE CAPTION}

Table 1 Proximate and ultimate analysis of DZ low-rank coal sample

Table 2 Physical properties and chemical compositions of the BFS

Table 3 The gasification rate equation and kinetic parameters of low-rank coal gasification with/without BFS 


\section{FIGURE CAPTION}

Fig. 1 The schematic diagram of the continuous experiment apparatus and primary reactor. (a) Experiment apparatus, (b) Primary reactor

Fig. 2 The schematic diagram of the thermo-gravimetric experiment apparatus

Fig. 3 The diagram of the thermo-gravimetric experiment procedure

Fig. 4 The distribution of product syngas fraction of DZ low-rank coal in lab-scale continuous gasification experiment $(\mathrm{S} / \mathrm{C}$ ratio $=2.0)$

Fig. 5 The characteristic of CE, CGE, PE and LHV with different temperatures $(\mathrm{S} / \mathrm{C}$ ratio $=2.0)$

Fig. 6 Effect of $\mathrm{C} / \mathrm{S}$ ratio on carbon conversion during the gasification of DZ low-rank coal at different temperatures

Fig. 7 Effect of C/S ratio on reaction rate during the gasification of DZ low-rank coal at different temperatures

Fig. 8 Various mechanism models fitted with the carbon conversion of DZ low-rank coal gasification. (a). $\mathrm{T}=1573 \mathrm{~K}, \mathrm{~S} / \mathrm{C}$ ratio $=1: 0 ;$ (b). $\mathrm{T}=1623 \mathrm{~K}, \mathrm{~S} / \mathrm{C}$ ratio $=1: 0 ;(\mathrm{c}) . \mathrm{T}=1673 \mathrm{~K}$, $\mathrm{S} / \mathrm{C}$ ratio $=1: 0 ;(\mathrm{d}) . \mathrm{T}=1573 \mathrm{~K}, \mathrm{~S} / \mathrm{C}$ ratio $=1: 2 ;(\mathrm{e}) . \mathrm{T}=1623 \mathrm{~K}, \mathrm{~S} / \mathrm{C}$ ratio $=1: 2 ;(\mathrm{f}) . \mathrm{T}=1673 \mathrm{~K}$, $\mathrm{S} / \mathrm{C}$ ratio $=1: 2$

Fig. 9 The integrated catalytic mechanism of steam gasification in molten slag 